\title{
Application of Volumetric Method to the Assessment of Damage Induced by Action of Foreign Object on Gas Pipes
}

\author{
R. Adib, C. Schmitt, and G. Pluvinage
}

Laboratoire de Fiabilité Mécanique, Université de Metz-ENIM, Metz, France

удк 539.4

Применение метода объъемных измерений для оценки повреждений, вызванных воздействием инородных тел на газовые трубы

\author{
Р. Адиб, С. Шмитт, Г. Плювинаж \\ Лаборатория механической надежности, Университет г. Метц, Франция \\ Известнь три основньх типа повреждения труб газопроводов. Наибольиую опасность с \\ точки зрения надежности газовых трубопроводов представляют повреждения, вызваннье \\ воздействием инородньх предметов. Предложен объемный метод, который позволяет \\ учитьвать влияние геометрического эффекта появления выбоин и концентраторов напря- \\ жений в трубах на характеристики хрупкого или упругопластического разрушения труб, \\ подвергнутьх внутреннему давлению. Рассмотрено применение объемного метода при \\ наличии внечнего продольного поверхностного концентратора напряжения в газовой трубе. \\ Описана специальная методика SINTAP, с помощью которой можно вычислить значение \\ коэффициента запаса прочности.
}

Ключевые слова: трубопровод, разрушение, надрез, объемный метод, определение диаграмм поврежденности, запас прочности.

Introduction. Pipelines have been employed as one of the most practical and low price method for large oil and gas transport since 1950. The pipe line installations for oil and gas transmission are drastically increased in last three decades. Consequently, the pipeline failure problems have been increasingly occurred. The economical and environmental and eventually in human life considerations involve the current issue as structural integrity and safety affair. The explosive characteristics of gas provide high wakefulness about the structural integrity. Therefore, the reliable structural integrity and safety of oil and gas pipelines under various service conditions including presence of defects should be warily evaluated. The external defects, e.g., corrosion defects, gouge, foreign object scratches, and pipeline erection activities are major failure reasons of gas pipelines. A typical example of a corrosion defect is given in Fig. 1. According to numerous design codes, this kind of defects is considered as a semi elliptical crack-like surface defect of aspect ratio $a / c$. This aspect ratio varies in range [0.1-1] depending on corrosion rate anisotropy. Another example of dents produce by impact of foreign object (IFO) is presented in Fig. 2.

Dents or gouges are considered as one the major reasons causing pipeline defects. These defects contain complex geometries and they are mostly assumed as semi-elliptical crack shape in some well-known codes. 


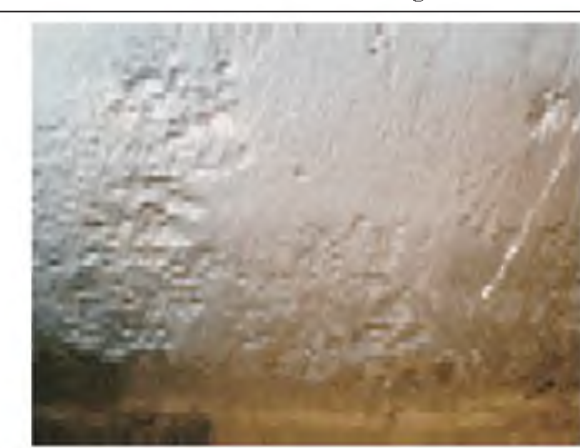

Fig. 1. Example of corrosion defect on pipe

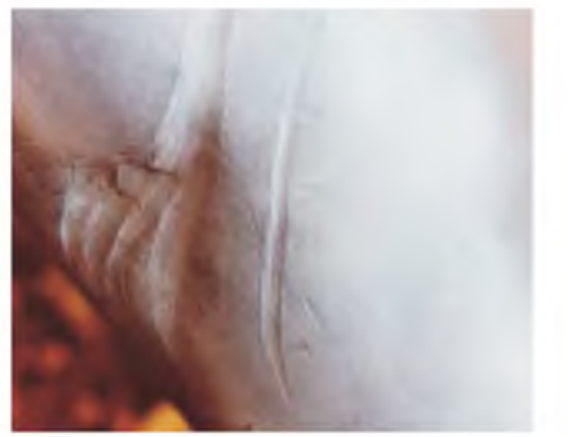

Fig. 2. Example of dents on pipe.

Several types of pipes failures can be distinguished as longitudinal, circumferential or helicoidally failures. These types depend mainly on pipe diameter. For small diameter pipes, where bending stresses are predominant, circumferential failure occurs. For large diameter, hoop stresses are more important than bending stresses and longitudinal failure appears. When bending and hoop stresses are of the same importance, fracture path becomes helicoidal.

In this paper, damage induced by foreign object is assumed to be represented by a surface elliptical notch. For conservative reason, this notch assumed to be longitudinal. The pipe is submitted to an internal pressure of 70 bars which is the service pressure. Stresses at notch tip have been computed by finite-element method (FEM) and local stress distribution parameters such as effective stress and distance have been extracted. They are introduced in the concept of notch fracture mechanics [1]. The classical failure assessment diagram (FAD) has been modified for this purpose and the safety factor associated to service pressure has been obtained.

1. FAD and SINTAP Procedure. The SINTAP (Structural Integrity Assessment Procedure for European Industry) is based on failure assessment diagram. In the FAD method, a failure curve or "interpolating curve" is used to assess the failure zone, safe zone, security and safety factor. In Fig. 3, a typical failure assessment diagram is illustrated.

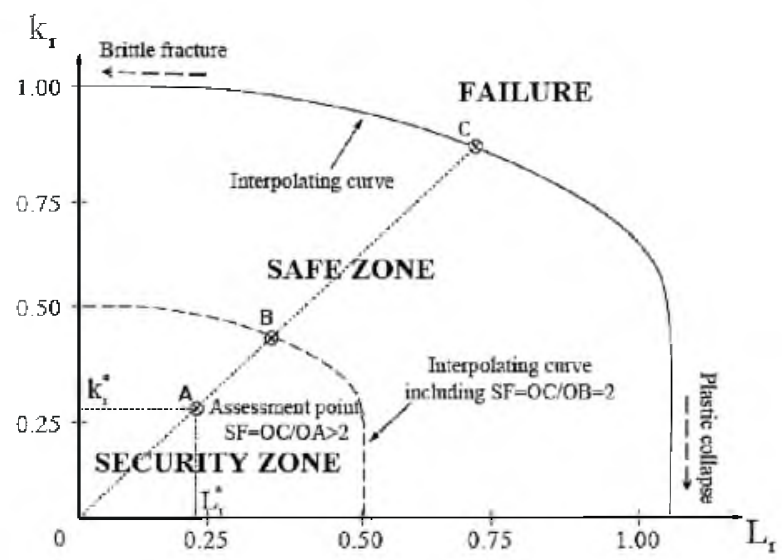

Fig. 3. Typical presentation of failure assessment diagram. 
The failure assessment diagram accounts any kinds of failure: plastic collapse as well as brittle fracture and elastic-plastic failure. The failure assessment diagram exhibits a failure curve as the critical non dimensional stress intensity factor versus non dimensional stress or loading parameter and has been applied into several codes in conjunction with the structural integrity of cracked structures. The main objective of the present study is to imply the interpolating curve and FAD concept into notch problem because the fracture mechanics is based on crack and not on blunt defects such as dents. For that, the non dimensional stress intensity factor $k_{r}$ is replaced by the non dimensional stress intensity factor $k_{r, \rho}$. The SINTAP procedure [2] is divided into several distinct levels. A default level without yield stress assumptions is used according to limited knowledge of the mechanical behavior of the material (API X52). The mathematical expressions of SINTAP default level procedure with the aforementioned assumption can be written as below [1]:

$$
f\left(L_{r}\right)=\left[1+\frac{L_{r}^{2}}{2}\right]^{-1 / 2}\left[0.3+0.7 \exp \left(-0.6 L_{r}^{2}\right)\right] \text { for } \quad 0 \leq L_{r} \leq 1,
$$

where

$$
L_{r}^{\max }=1+\left(\frac{150}{\sigma_{Y}}\right)^{2.5}
$$

$f\left(L_{r}\right), L_{r}, L_{r}^{\max }$, and $\sigma_{Y}$ are respectively interpolating function, nondimensional loading or stress based parameter, the maximum value of nondimensional loading or stress based parameter, and yield stress, respectively.

In the present study, dents are considered as notches and not considering as crack like defects and in this case, the interpolation function $f\left(L_{r}\right)$ given by Eq. (1) is taken as similar because we use non dimensional parameter and the notch stress intensity factor (SIF) is affected similarly than the SIF.

2. Volumetric Method and Notch Stress Intensity Factor. The critical notch stress intensity factor is a local fracture criterion that assumes that the fracture process requires a certain fracture process volume. This volume is assumed as cylinder with diameter called effective distance. Determination of this effective distance is based on the bi-logarithmic elastic-plastic stress distribution because the fracture process zone is the highest stressed zone. This zone is characterized by an inflexion point on the stress distribution at the limit of zone $I I$ and zone $I I I$ in Fig. 4. Justification of this method has been given in reference [1] The determination of the effective distance is accomplished using the minimum of the relative stress gradient $\chi$ which corresponds to this inflexion point. The $\chi$ value is given by

$$
\chi(r)=\frac{1}{\sigma_{y y}(r)} \frac{\partial \sigma_{y y}(r)}{\partial r},
$$

where $\chi(r)$ and $\sigma_{y y}$ are the relative stress gradient and maximum principal stress or crack opening stress, respectively. 


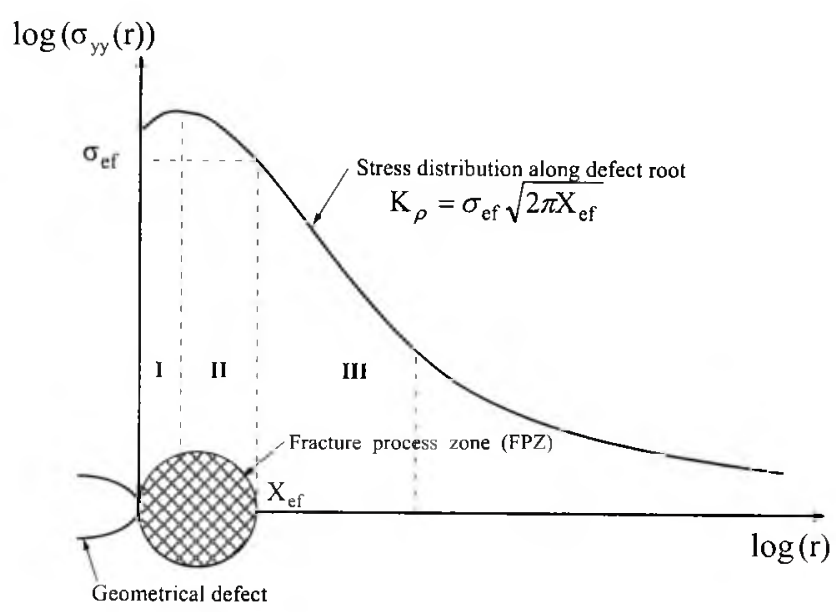

Fig. 4. Schematic elastic-plastic stress distribution along notch ligament and notch stress intensity virtual crack concept.

The effective stress is considered as the average value of the stress distribution inside the fracture process zone. This stress distribution is corrected by a weight function in order to take into account the distance from notch tip of the acting point and the stress gradient at this point

$$
\sigma_{e f}=\frac{1}{X_{e f}} \int_{0}^{X_{e f}} \sigma_{y y}(r) \Phi(r) d r
$$

where $\sigma_{e f}, X_{e f}, \sigma_{y y}(r)$, and $\Phi(r)$ are effective stress, effective distance, opening stress and weight function, respectively.

In Table 1, some proposed weight functions are shown.

The notch stress intensity factor describes the stress distribution in zone III. By extension the notch stress intensity factor can be defined as a function of the effective distance and effective stress [2]:

$$
K_{\rho}=\sigma_{e f} \sqrt{2 \pi X_{e f}} \text {. }
$$

At failure, the notch stress intensity factor reaches the critical value $K_{\rho, c}$. The non dimensional parameter $k_{r}$ is denoted for a notch as

$$
k_{r}=\frac{K_{\rho}}{K_{\rho, c}} .
$$

The loading parameter in FAD can be written as follows:

$$
L_{r}=\frac{\sigma_{g}}{\sigma_{f}}
$$


where $\sigma_{g}$ and $\sigma_{f}$ are the global stress and flow stress $\left(\sigma_{f}=\left(\sigma_{Y}+\sigma_{u}\right) / 2\right)$, respectively. In the plane $\left[L_{r}, k_{r}\right]$, the assessment point is defined by the coordinates $\left[L_{r}^{*}, k_{r}^{*}\right]$

$\mathrm{T}$ a b 1 e 1

Different Proposed Weight Functions for Calculating Effective Stress around Notch Tip

\begin{tabular}{|c|c|c|}
\hline Weight function & $\Phi(r)$ & $\sigma_{e f}$ \\
\hline Unit weight function & $\Phi(r)=1$ & $\sigma_{e f}=\frac{1}{X_{e f}} \int_{0}^{X_{e f}} \sigma_{y y}(r) d r$ \\
\hline $\begin{array}{c}\text { Peterson's } \\
\text { weight function [3] }\end{array}$ & $\Phi(r)=\delta\left(r-X_{e f}\right)$ & $\sigma_{e f}=\frac{\sigma_{y y}\left(X_{e f}\right)}{X_{e f}}$ \\
\hline $\begin{array}{c}\text { Qylafku's } \\
\text { weight function [4] }\end{array}$ & $\Phi(r)=1-r \chi(r)$ & $\sigma_{e f}=\frac{1}{X_{e f}} \int_{0}^{X_{e f}} \sigma_{y y}(r)[1-r \chi(r)] d r$ \\
\hline $\begin{array}{c}\text { Kadi's } \\
\text { weight function [5] }\end{array}$ & $\Phi(r)=\exp [r \chi(r) / 2]$ & $\sigma_{e f}=\frac{1}{X_{e f}} \int_{0}^{X_{e f}} \sigma_{y y}(r) \exp [r \chi(r) / 2] d r$ \\
\hline $\begin{array}{c}\text { Modified Qylafku's } \\
\text { weight function [6] }\end{array}$ & $\Phi(r)=1-r|\chi(r)|$ & $\sigma_{e f}=\frac{1}{X_{e f}} \int_{0}^{X_{e f}} \sigma_{y y}(r)[1-r|\chi(r)|] d r$ \\
\hline
\end{tabular}

As shown in Fig. 3, the safety factor $S F$ is defined by the radial distance ratio between interpolating failure curve and assessment point according to the SINTAP procedure $(S F=O C / O A)$.

By divided the FAD parameter by a conventional safety factor (a value of 2 is mostly used for practical engineering applications), we defined the security curve. Similarly, the security factor $S F$ obtained according to the procedure $(S F=O B / O A)$.

3. Mechanical Properties of API X52. The API X52 was the most common gas pipelines material for transmission of oil and gas during 1950-1960. The chemical composition of API X52 is shown in Table 2.

$\mathrm{T}$ a b 1 e 2

Chemical Composition of API X52 (wt.\%)

\begin{tabular}{|c|c|c|c|c|c|c|c|c|c|c|}
\hline $\mathrm{C}$ & $\mathrm{Mn}$ & $\mathrm{Si}$ & $\mathrm{Cr}$ & $\mathrm{Ni}$ & $\mathrm{Mo}$ & $\mathrm{S}$ & $\mathrm{Cu}$ & $\mathrm{Ti}$ & $\mathrm{Nb}$ & $\mathrm{Al}$ \\
\hline 0.22 & 1.22 & 0.24 & 0.16 & 0.14 & 0.06 & 0.036 & 0.19 & 0.04 & $<0.05$ & 0.032 \\
\hline
\end{tabular}

In Table 3, mechanical properties of API X52 are presented. This material exhibits a large elongation and ductile behavior is expected.

In Fig. 5a, the true stress-strain curve of API X52 including above hardening exponent and coefficient is illustrated. The fracture toughness has been obtained by experimental studies which are presented in Fig. 5b. This special device and specimen have been developed due to impossibility to get flat specimen from small-diameter pipes. 
$\mathrm{T}$ a $\mathrm{b} 1 \mathrm{e} 3$

Mechanical Properties of API X52

\begin{tabular}{|c|c|c|c|c|c|c|}
\hline$E, \mathrm{GPa}$ & $\sigma_{Y}, \mathrm{MPa}$ & $\sigma_{u}, \mathrm{MPa}$ & $A, \%$ & $n$ & $K, \mathrm{MPa}$ & $K_{\rho, c}, \mathrm{MPa} \sqrt{\mathrm{m}}$ \\
\hline 203 & 410 & 528 & 32 & 0.164 & 876 & 116.6 \\
\hline
\end{tabular}

Note. $E, \sigma_{Y}, \sigma_{u}, A, n, K$, and $K_{\rho, c}$ are the modulus of elasticity, yield stress, ultimate stress, relative elongation, hardening exponent, hardening coefficient, and fracture toughness, respectively

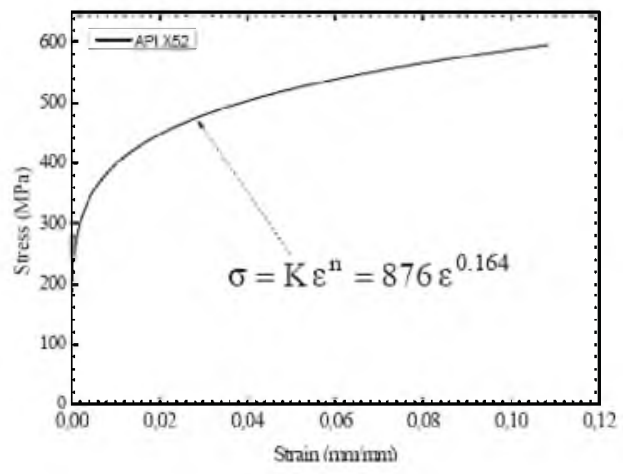

$a$

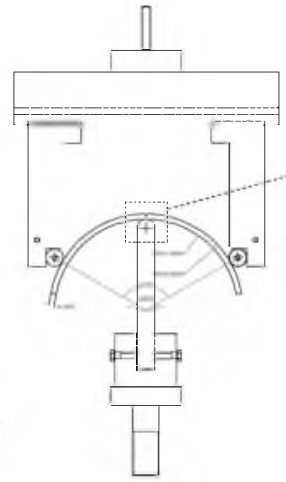

$b$

Fig. 5. Simple tension test results as true stress-strain curve for API X52 material $(a)$ and experimental test setup for extracting the fracture toughness $(b)$.

From this test, the critical load is extracted. Then stress distribution is computed by FEM. The values of effective stress and distance are introduced in Eq. (4). We note that fracture toughness which depends on notch radius and pipe curvature is obtained with the same constraint that in pipe.

4. Pipe and Defect Geometries. In Fig. 6, the geometrical configurations of pipe and defect are presented. Pipe has an external diameter of $219.1 \mathrm{~mm}$ and a wall thickness of $6.1 \mathrm{~mm}$. The service pressure of the gas pipe is at maximum 70 bars.

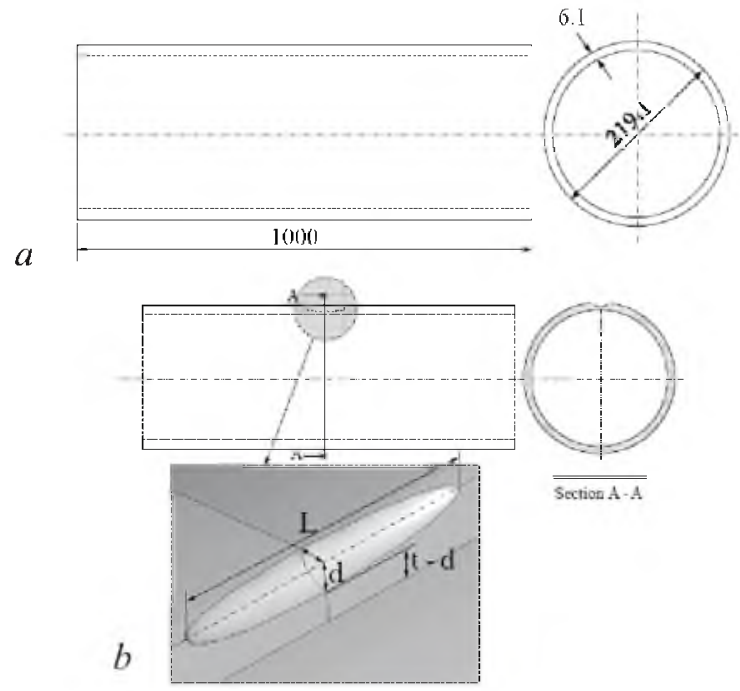

Fig. 6. Pipe geometry (all dimensions in $\mathrm{mm})(a)$; central semi-elliptical defect $(a=t / 2$, $a / c=0.1)(b)$. 
The defect depth for all models is equal to one-half of pipe thickness and the defect aspect ratio is considered as $0.1(a / c=0.1)$.

5. FEM Assessment of Stress Distribution. To analyze the stress distribution, one-fourth symmetry consideration including 8-node solid element mesh has been employed. In Fig. 7, the geometrical and mesh density around the semi-elliptical defect is shown for considered pipeline. The main goal in this stage is to determine and evaluate the stress distribution pattern and corresponding parameters such as effective stress and effective distance. To tease out the boundary conditions side effects and obtain pure induced stress distribution due to the defects existence, it is assumed that the mentioned defects are mathematically positioned into an infinite pipeline. It is necessary to remind that the present assumption can be physically fulfilled by sufficient pipe length which can be found via trial and error procedure. An example of the computed stress distribution is given in Fig. $7 b$.

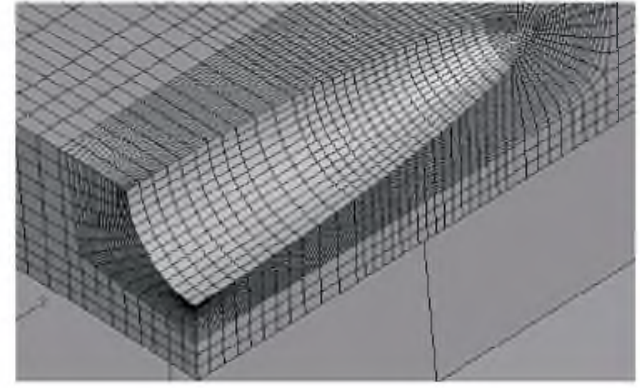

$a$

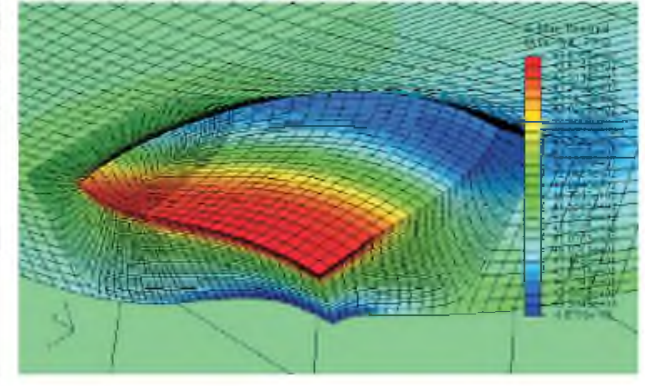

$b$

Fig. 7. Detail mesh density around the selected semi-elliptical defect $(a)$; stress distribution pattern (b)

6. Applied Notch Stress Intensity Factor and Safety Factor. As discussed in section 2, the notch stress intensity concept is implemented into the SINTAP procedure (default level). To predict the structural integrity of the present semi-elliptical defect, it is required to acquire the opening stress along the ligament. The finite element analysis provides the necessary parameters for

"Notch-Based Failure Assessment Diagram" (NBFAD). In Fig. 8, the stress distribution along ligament is shown as bi-logarithmic and diagram. The bi-logarithmic diagram easily highlights the three mentioned zones and the effective distance, effective stress and other required parameters are calculated for NBFAD.

T a b 1 e 4

Coordinates of the Failure Assessment Point

\begin{tabular}{|c|c|c|c|c|c|c|}
\hline $\begin{array}{c}\sigma_{e f}, \\
\mathrm{MPa}\end{array}$ & $\begin{array}{c}X_{e f}, \\
\mathrm{~mm}\end{array}$ & $\begin{array}{c}K_{\rho}, \\
\mathrm{MPa} \sqrt{\mathrm{m}}\end{array}$ & $\begin{array}{c}\sigma_{\theta \theta}: \\
\mathrm{MPa}\end{array}$ & $\begin{array}{c}\sigma_{0}, \\
\mathrm{MPa}\end{array}$ & $k_{r}$ & $S_{r}$ \\
\hline 343 & 0.67 & 15.8 & 125 & 469 & 0.136 & 0.27 \\
\hline
\end{tabular}

Note. $\sigma_{\theta \theta}=p D / 2 t, \sigma_{0}=\sigma_{u}+\sigma_{Y} / 2$, and $S_{r}=\sigma_{\theta \theta} / \sigma_{0}$. 


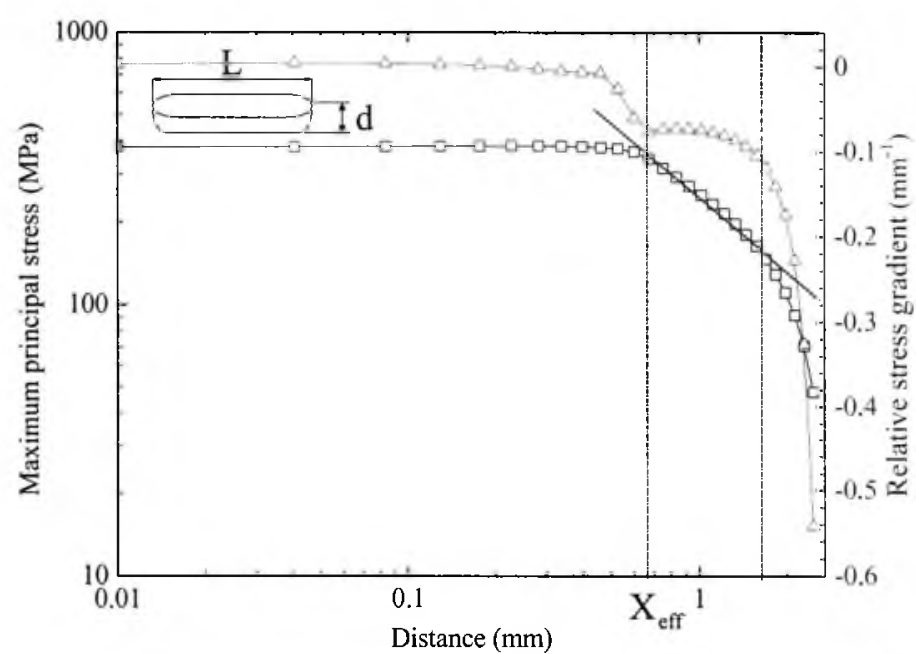

Fig. 8. Bi-logarithmic stress distribution and relative stress gradient versus ligament distance and corresponding relative stress gradient $\left(X_{e f}=0.6736 \mathrm{~mm}, \sigma_{e f}=343.45 \mathrm{MPa}\right)$

The notch-based failure assessment diagram or so called "NBFAD" safety factor evaluation is presented in Fig. 9. The coordinates of the assessment point are given in Table 4.

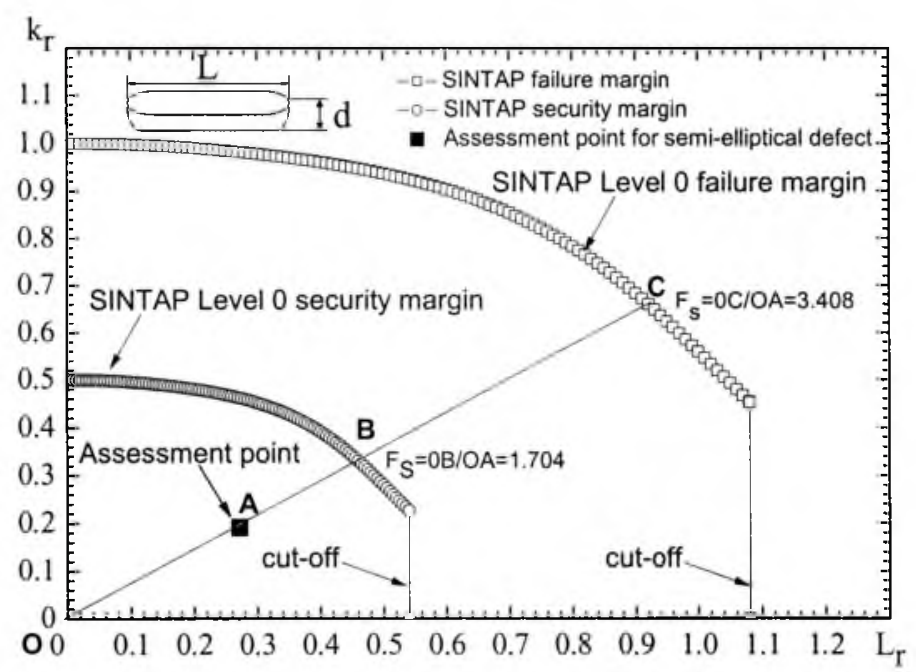

Fig. 9. Structural integrity evaluation via SINTAP procedure according to the FEM outcomes for semi-elliptical defects.

As shown in Fig. 9, the safety factor and security factor are elucidated by radial distances ratio $(O C$ or $O B$ over $O A)$. Therefore, the extracted assessment point is positioned in safety and security zone.

Conclusions. The failure hazard for gas pipeline including semi-elliptical gouge defect is evaluated via SINTAP and elastic finite element method outcomes. SINTAP procedure has been modified in order to take into account that the defect is not a crack like defect but has a finite tip radius. For that, the concept of notch 
stress intensity described by effective stress and effective distance has been used and the corresponding fracture toughness measured using a special specimen called "roman tile." The classical deterministic approach leads to the conclusion that the necessary engineering safety factor of a gas pipe exhibiting a severe gouge type defect (depth equal to half the thickness) and submitted to an internal service pressure of 70 bars which is normal service pressure condition for gas transmission is widely satisfy $(S F=3.4>S F=2)$. The security factor has been found equal to 1.7

\section{Резюме}

Відомо три основні типи пошкодження труб газопроводів. Найбільш небезпечними 3 точки зору надійності газових трубопроводів є пошкодження внаслідок дії сторонніх предметів. Запропоновано об’ємний метод, який дозволяє враховувати вплив геометричного ефекту появи вибоїн та концентраторів напружень у трубах на характеристики крихкого або пружно-пластичного руйнування труб, що зазнають дії внутрішнього тиску. Розглянуто використання об'ємного методу за наявності зовнішнього поздовжнього поверхневого концентратора напружень у газовій трубі. Описано спеціальну методику SINTAP, за допомогою якої можна знайти коефіцієнт запасу міцності.

1. G. Pluvinage, Fracture and Fatigue Emanating from Stress Concentrators, Kluwer Academic Publishers, Dordrecht (2003).

2. SINTAP. Structural Integrity Assessment Procedure, Final Report E-U Project BE95-1462, Brite EURAM Programme, Brussels (1999).

3. R. E. Peterson, "In metal fatigue," in: G. Sines (Ed.), McGraw-Hill (1959), pp. 293-306.

4. G. Qylafku, Z. Azari, N. Kadi, M. Gjonaj, G. Pluvinage, "Application of a new model proposal for fatigue life prediction on the notches and key-seats," Int. J. Fatigue, 21, 753-760, (1999).

5. N. Kadi, Ph.D. Thesis, University of Metz, Metz, France (2001).

6. H. Adib, J. Jeong, G. Pluvinage, and M. Lebienvenu, "Role of stress gradient at notch roots using volumetric method," Int. J. Fracture, Submitted, April (2005). 